\title{
An Evaluation Of Indicators Of Socio-Economic Deprivation: A Case Study Of The Slums Of Karachi, Pakistan
}

\author{
Kaneez Fatima Mamdani \\ Department of Sociology \\ University of Karachi
}

\begin{abstract}
In Pakistan more than one third of its population continues to live below the poverty line (Economic Survey of Pakistan, 2013). Recent research has shown that poverty is wide spread in both urban and rural areas and it is not only rural phenomenon. Since the past few decades, Karachi has experienced an inflow of migrants from all parts of Pakistan in search of better opportunities. Karachi has about 650 katchi abadis (squatter settlements) which are home to $50 \%$ of city's population (Sindh Katchi Abadis Authority 2006). The objective of this study is to measure and analyse the nature and level of socio-economic deprivation as well as to find out the different forms of socio-economic deprivation. It is an exploratory cross-sectional study. Primary data is collected from 497 households of seven katchi abadis of Karachi to study the problem. Statistical tools of analysis i.e. coefficients of variance are used to analyse the relationship between two variables and indices of multiple deprivation are constructed to compute the different domains and levels of deprivation. It is evident from the outcomes of the findings of domains of deprivation that the significant proportion of population of Katchi Abadis i.e. approximately $50 \%$ of the households suffers from multiple deprivation. The findings emphasize that all settlements have deprivation in all domains (education, economic, housing quality and housing services deprivation, health deprivation); however each settlement has different issues and concerns priority wise. Index of multiple deprivation show $49 \%$ of households living below poverty line (US\$ 1.25) experience multiple deprivation. The findings also reveal that $60 \%$ of households highly to moderately deprived as regards to levels of deprivation while $40 \%$ has low deprivation level. In order to increase the standard of living on the grass-root level, "Living Wages" should be used as the standard to measure people's socio-economic wellbeing instead "Poverty" to maintain a decent standard of living for families of different sizes. Policies should be designed to decrease the level of unemployment on a scale needed for long term poverty alleviation, by creating environment that is conducive to private economic activity at the grass root level.
\end{abstract}

Keywords: Socio-Economic Deprivation; Indices of Multiple Deprivation, Poverty Line, Squatter Settlements.

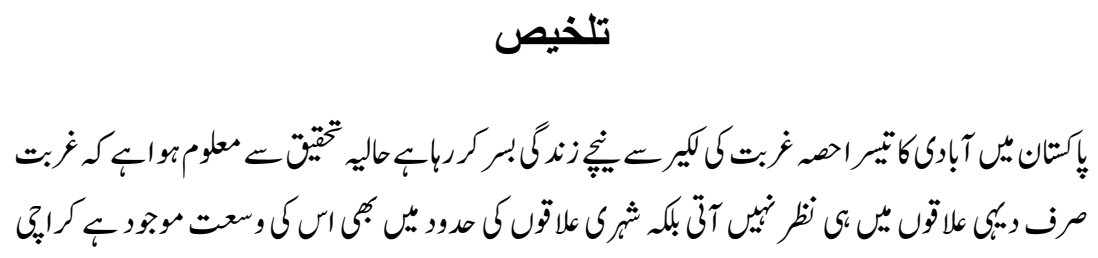




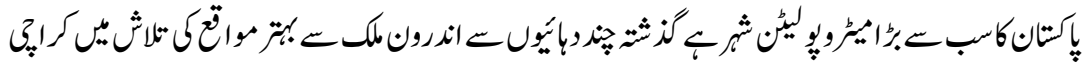

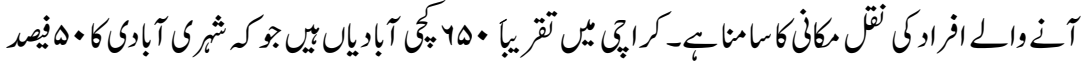

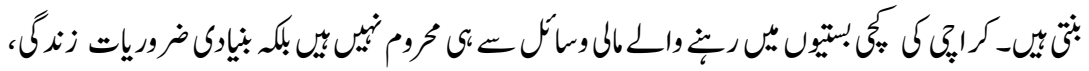

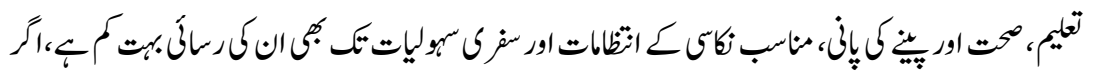

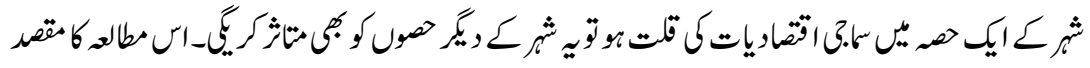

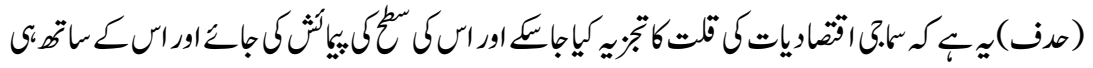

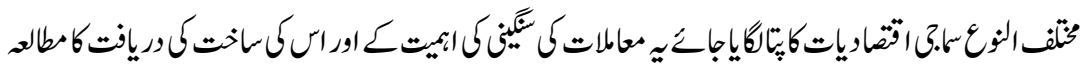

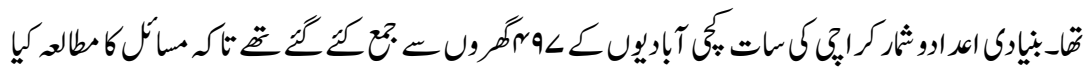

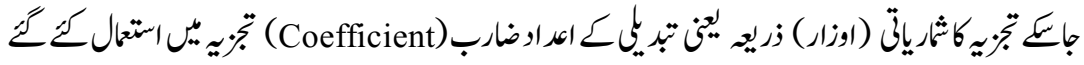

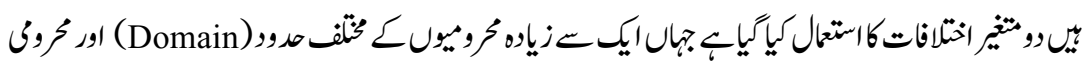

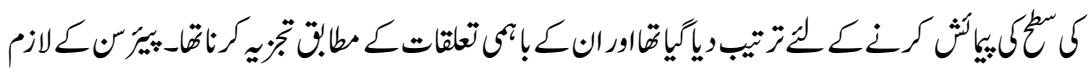

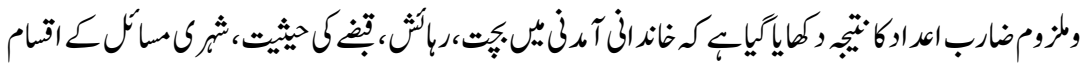

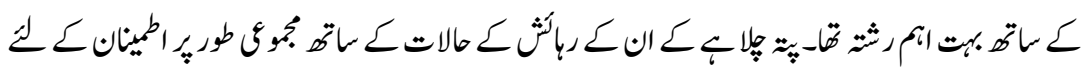

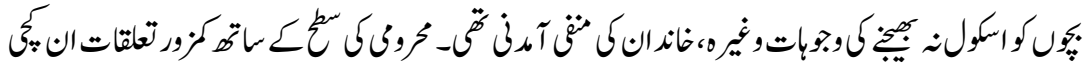

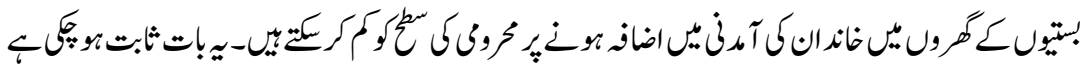

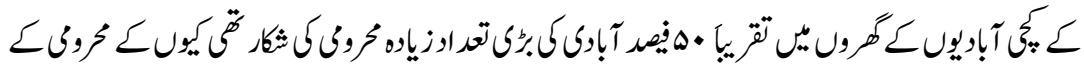

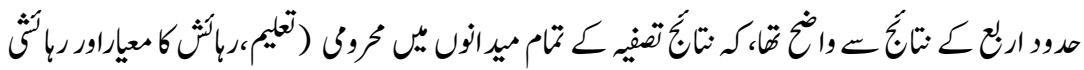

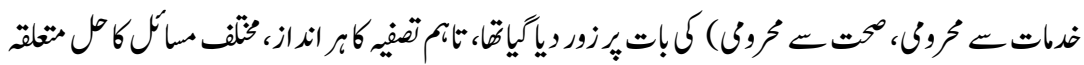

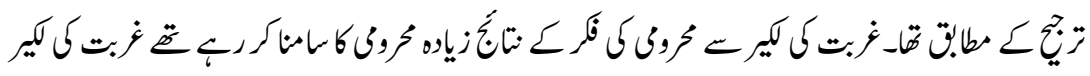

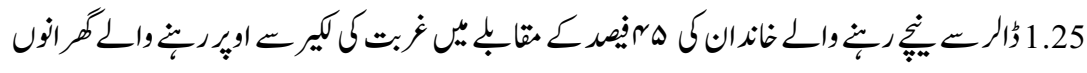

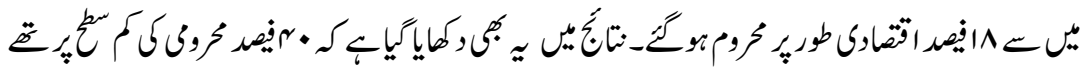

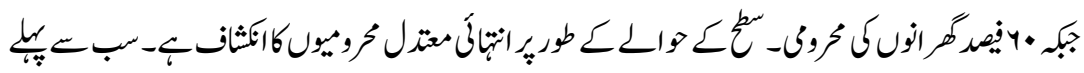

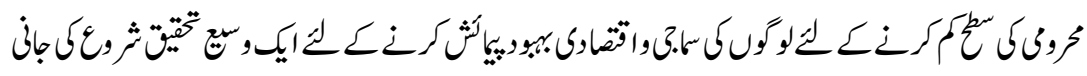

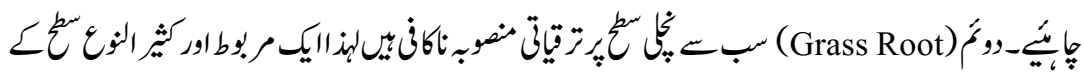

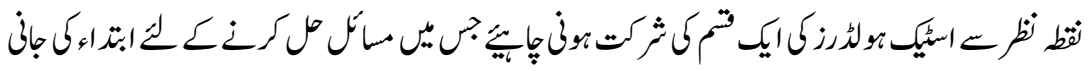

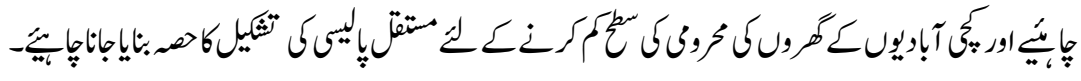

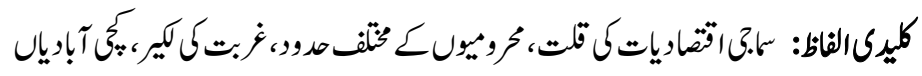




\section{Introduction}

"Middle Income Countries" of the world have significantly enhanced the standard of their economic indicators during last decade or so but inequality in income and poverty persists. Disparities in accessibility to education, health, infrastructure and other utility services have further intensified the situation of deprivation. Pakistan, like many middle-income countries is facing other relentless challenges that are not possible to solve in the shortest period of time.

The poverty rate in urban areas is increasing in both developing and least developed countries. Despite the rapid pace of 8.2\% World Bank (2007) in South Asian nations, it still has some of the worst human deprivation in the world. Among South Asian nations, Pakistan is the one in which the incidence of poverty and hunger is very high and rising day-by-day. More than one third of Pakistan's population is living under US\$1.25 a day (Poverty line) and there are disquieting gaps in the social attainments even after six decades of its development.

The people residing in these squatters are deprived of sufficient income, educational facilities, health facilities, clean potable water, proper sanitation system, transportation etc. Recent researches have shown that socio-economic deprivation is wide-spread in urban as well as rural areas and this phenomenon is not restricted to rural areas only. However, attempts to solve the problems have been primarily focused upon rural areas instead of towns and cities. The major cities of Pakistan like Karachi and Lahore are not only facing the huge challenge of curtailing socio-economic problems but also have to deal with both international and national political conflicts which are creating hindrances in development and progress of these cities.

Although, Pakistan is basically an agricultural country and large proportion of its population still reside in rural areas, since 1960s persistence and accelerated trend towards urbanization has been clearly visible. This effect of urbanization is quite visible in cities, like Karachi and Lahore. There is no doubt that urban growth is attributed to the rate of natural increase of population within the cities, but the rapid growth in urban concentration is also due to migration from rural areas.

Karachi is the mega metropolis of Pakistan. It is the industrial, commercial and trade centre of the country and has a well-developed economy which continues to show high growth rate. Since the past few decades, Karachi has experienced an inflow of migrants from all parts of Pakistan in search of decent livelihood and better opportunities. Many of the migrants to large cities settle in slum areas termed as katchi abadis. The term slum denotes an extremely bad infrastructure, unsanitary conditions and occupants belonging to the lowest income group. 
Most families who have arrived and are arriving in this mega city have been pushed into slums where they live with substandard housing, inadequate infrastructures, insufficient health care services, lack of security, almost no sanitation and limited water supply (WHO, 2012). Karachi has about 650 katchi abadis which are home to more than $50 \%$ of its population (SKAA, 2006).

\section{The Concept of Socio-Economic Deprivation}

Sociologically deprivation is explained as a condition of visible and noticeable shortcomings comparative to the native group, society or country to which a person, household or a group belongs. Some individuals or households are suffering from multiple deprivations and others only one type of deprivation. A household (or alternatively an individual or a family) is termed as deprived when their quality of life is much lower than the accepted minimum standards. Socioeconomic deprivation is seen not only in terms of lack of access to resources that sustain the body and soul together but also such necessary elements of contemporary life as education, communication with the rest of the world and social safety nets such as reasonably good health care system and food security systems as well. These broad areas of human wellbeing are the bases upon which battle against poverty has been launched (Aurora, 2004). Thus, socio-economic deprivation means inability to obtain housing quality and services, environment, educational, working and social condition generally regarded as acceptable and in harmony with the community.

\section{Determinants of Deprivation}

To understand the determinants of deprivation in all its dimensions it helps us to think in terms of people's asset as; human assets, natural assets, physical assets, financial assets and social assets (World Development Report, 2002). There are also numbers of other determinants of being deprived as; lack of income to obtain basic necessities - food, shelter, clothing and acceptable levels of health education, lack of access to job opportunities (urban), low standard of living, tenure insecurity (land \& housing) and increasing numbers of slums and squatter settlements. In this paper different domains of multiple deprivation were measured. Multiple deprivation is a general deprivation index which consists of many domains. It does not only view deprivation through low income only but it also considers many other variables or elements which reflect the general deprivation status of a person compared with the conditions of the society that a person lives with. The indicators of deprivations such as income, employment, education and training, housing, health care, access to services have to be combined to produce one index (Townsend \& et al., 1988). In this study, indicators used in different aspects of deprivation are education deprivation, 
housing quality deprivation, residential services deprivation, economic deprivation and health deprivation.

\section{Socio-Economic Deprivation Conditions in Pakistan}

Evidence from the FY2011 Household Integrated Economic Survey indicated a widening income gap between rich and poor, with income for $40 \%$ of the population growing more slowly than the average income of the others. With low investment and economic growth below the rate needed to support the predominately young population, the rich-poor income gap is set to increase further in Pakistan (ADB, 2012).

Pakistan's HDI (Human Development Index) value for 2015 was 0.538 - in the lowest human development category-positioning the country at 147 out of 187 countries and territories showing -1 gap in HDI ranking (Human Development Report, 2015). The National IMD (Index of Multiple Deprivation) was estimated at 30.3 indicating $30 \%$ of population was deprived with respect to selected sectors and indicators of IMD. In terms of regional IMDs, urban areas had 13.3 magnitude of deprivation.

In Pakistan $49.4 \%$ of the population suffer multiple deprivations while additional $11.0 \%$ are vulnerable to multiple deprivations. The breadth of deprivation (intensity) in Pakistan, which is the average percentage of deprivation faced by people in multidimensional poverty areas, was $52.1 \%$. The Multiple Poverty Index (MPI), which is the share of the population that is multi-dimensionally poor, adjusted by the intensity of the deprivations, was 0.230 .

Table: 1

Human Deprivation Profile of Pakistan, 2015

\begin{tabular}{|l|c|}
\hline HDI Rank & 147 \\
\hline HDI & 0.538 \\
\hline MPI & 0.230 \\
\hline Head Count & $49.5 \%$ \\
\hline Intensity of Deprivation & $52.1 \%$ \\
\hline Population Vulnerable to Poverty & $15.1 \%$ \\
\hline Population in severe poverty & $23.7 \%$ \\
\hline
\end{tabular}

Source: Human Development Report, 2015 \& OPHI, 2015

According to the headcount measures, $32.6 \%$ of the Pakistan population was currently living in poverty at the end of the 1990's while the headcount measure increased to $49.5 \%$ in 2015 as shown in Table 1. 


\section{Socio-Economic Deprivation in Karachi}

Karachi was the first capital of Pakistan after its independence in 1947. Karachi became premier part of the new country and a centre of business and administration. Trend of population of Karachi shows (Chart 1) a continuously high growth of population. Karachi's population is estimated to be more than 20 million. Karachi's current annual growth rate is more than $5 \%$. This percentage also includes internal migration where more than 45,000 migrants are coming to Karachi every month (Retrieved from CDGK (City District Government of Karachi) official Website).

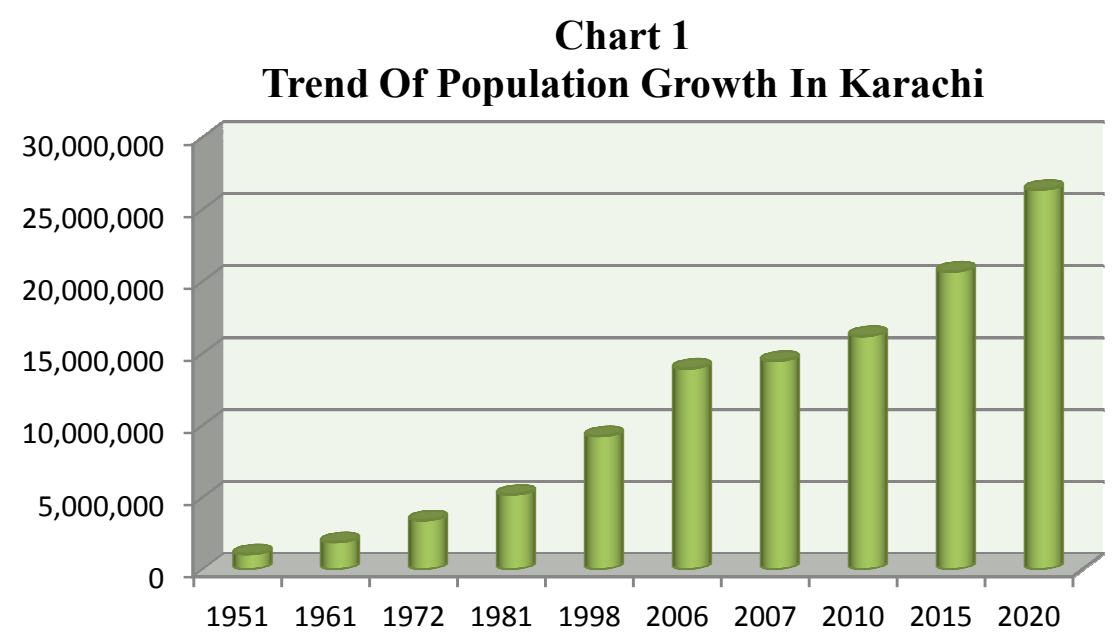

Source: Official website of CDGK (2015, 2020 estimated projection)

Due to large scale migration disorganized land occupation occurred in the same proportion which resulted in the formation of slums (Katchi abadis) in Karachi's outskirts and in vacant urban lands. The settlements density has increased overtime as political instability prevented coherent urban planning. In 1960's and 1970's rural-urban migration had increased due to education and job opportunities in Karachi. Since 1988 Karachi has been going through ethnic, sectarian and political conflicts which have created problems of unemployment, housing facilities and many other problems have led to more informal settlements in Karachi (United Nations Human Settlements Programme, 2011).

The World Bank researchers believed that Karachi was one of the fastest growing mega cities of the world and now it is ranked as the 7th largest city of the world. Today, Karachi houses around $8.8 \%$ of Pakistan's total population and $24 \%$ of the urban population. According to the SKAA report (2005), there were 539 Katchi abadis in Karachi. An estimated $40 \%-60 \%$ of the urban population of Karachi lives in katchi abadis. These katchi abadis suffer from many Socio-economic 
problems including poor living conditions, lack of basic amenities, lack of adequate housing, lack of education, and lack of health facilities.

Within the sprawling metropolis of Karachi, poverty levels are different in each of the 18 towns of Karachi (now five districts). Military areas have the lowest rates of poverty. $40 \%$ of population in cantonments are living under poverty. Commercial areas like Sadar, Gulberg and Jamshed towns have 44\% poverty. Nazimabad town is a middle income group area with $46 \%$ of its residents are poor whereas labour class and katchi abadies have the highest rates of poverty as Orangi Town has 57\%, Gadap and Landhi Towns have 53\% each while Malir Town has $52 \%$ of poor populace.

Katchi Abadis are containing people above their capacities, hence finding it difficult to meet everyone's needs. The presence of migrants in Karachi has caused a number of problems in the socioeconomic structure of the city. Living in a Katchi Abadi is itself an important indicator of deprivation such as poor infrastructure services, poor living conditions and surviving under stress due to political unrest and constant threat of eviction. There has been some development in all human deprivation indicators particularly in major cities of Pakistan. Karachi is also no exception but katchi abadis of Karachi are by far away from achieving the goals set in MDGs (Millennium Development Goals) for 2015.

\section{Literature Review}

A study by Pasha and Pasha (2002) showed the estimates of the overall costs of living index for each city and Karachi was found to be the most expensive city of Pakistan. Idrees and Ahmad (2002) analysed trends in income and consumption inequality in Pakistan over the past 30 years using six alternative inequality indices and found household size to be key factor in estimating the extent of inequality in households. Jamal \& et al (2003) study's main purpose was to describe the overall picture of multiple deprivation, based on the combined education, health, housing quality, housing services and employment sectoral indices. The major findings indicated that among the persons residing in high deprivation, 18 million belonged to Punjab, 9 million each to Khyber Pakhtunkhwa and Sindh, and 6 million to Balochistan. Kalim \& Bhatty (2006) calculated the distinct socio economic deprivations of dwellers of squatter settlements/Katchi Abadis. The findings from the Socio Economic Opportunity Index (SEOI) indicated that $65.6 \%$ residents were deprived of primary social and economic opportunities. Abbas \& et al (2010) study dealt with the pattern of Katchi Abadies of Karachi taking into account the area and population as main parameters. Katchi Abadies were selected from five districts (old system). Total of 100 Katchi Abadies were studied. The findings of the model showed that uniformity was not present in Katchi Abadies. Qureshi (2010) paper indicated that half of Karachi's population is living in Katchi abadies and $40 \%$ of its population 
is suffering from poverty. Jamal (2012) \& Manzoor \& et al (2011) studies' analysed disparities among provinces and districts for the years 2011, 2009 and 2005 with respect to household socio-economic deprivations. The National IMD was estimated at 30.3 for the year 2011. The estimated number indicated that 30 $\%$ of population was deprived in 2011 with respect to selected sectors and indicators. In terms of regional IMDs, urban areas had 13.3 magnitude of deprivation. Qadeer (1983) examined the rapid growth of cities leading to shortage of housing units. During the industrial expansion phase when requirement for housing in Lahore did not encounter with the supply; the poor people had no alternative but to settle in illegal land creating Katchi Abadies (squatter settlements). Qureshi (1982-84), Asghar (1984), Chaudhry (1991) and Kazmi (1999) focused on the evaluation of socio economic opportunities and environmental conditions of Katchi Abadies of Lahore, Pakistan. The researchers established that Katchi Abadies had relatively high rates of infant mortality, water borne diseases, poor sanitation system and hygiene and inadequacy of basic services. Qureshi \& et al (1988) carried out a study to assess the project that was initiated in 1981-1984 by the government to improve the living conditions of Katchi Abadis (squatter settlements) in Lahore. They established that only through income residents of katchi abadies could not improve their living conditions. Balquees \& Hamid (1989) paper studied the conditions of women in Katchi Abadis of Rawalpindi. The researchers found that women were in more vulnerable conditions regarding their health and education. Hina (1992) highlighted the depressing conditions of occupants of Katchi Abadis of Lahore. She also studied the role of government in the enhancement of squatter settlements. After analysing the problems of inhabitants, she concluded that squatter settlements could not be upgraded without community's participation at every step of a way. Zaman \& Ara (2002) described that rapid growth in urban areas caused the spread of slums. In Pakistan costly residences in the formal sector have given rise to the informal settlement often over crowded with unhygienic conditions.

\section{Objectives}

- To find out the nature of socio-economic deprivation of the residents of the Katchi Abadis.

- To gather evidence to help characterise and compute the distinctive domains and levels of socio-economic deprivation of the residents of the katchi abadis/squatter settlement.

\section{Research Methodology}

The present study is based on quantitative paradigm and is exploratory in nature. The Universe of the present study includes seven Katchi Abadis of Karachi. The total population in these settlements is 1901 households. Sample size calculated 
for this study was 510 (elapsed sampling units 13). Two different probabilitysampling methods were used for the distribution of sample and data collection. Stratified sampling method was used for determination of sample size and allocation of sample size (Babbie, 2004). Systematic random sampling was used for the selection of households. In this research, researcher has employed interview schedule for the collection of data. SPSS was used for the analyses of the data. The researcher has employed more than one method for the analysis of the data to achieve the objectives of the study. To analyse the relationship among variable, Karl Pearson's correlation coefficient was used. Index of multiple deprivation was computed by employing the methodology used by UNDP (1997), HDR South Asia (1998), SPDC (2001) and Jamal et al (2003). The Index of Multiple Deprivation (IMD) was based on the principle that deprivation is composed of multiple dimensions. These dimensions or sectors reflect different aspects of deprivations. Each sector is made up of a number of indicators. This application was performed for all the indices namely;

1. Multiple Deprivation

2. Education Deprivation

3. Economic Deprivation

4. Housing Quality Deprivation

5. Housing/Residential Services Deprivation

6. Health Deprivation

The following formula was used to derive IMD.

$$
\mathrm{IMD}=[1 / 5 *\{(\mathrm{E}) \alpha+(\mathrm{L}) \alpha+(\mathrm{HQ}) \alpha+(\mathrm{HS}) \alpha+(\mathrm{HH}) \alpha\}] 1 / \alpha
$$

The overall Index of Multiple Deprivation was conceptualised as a weighted area level aggregation of the specific dimensions of deprivation.

\section{Discussion and Conclusions}

9.1 Table number 2 (Appendix) shows correlation coefficient of family income with eleven indicators: Family income and standard of living had significant but negatively weak correlation of -0.298 between them. Researcher had observed during her research that basically income distribution and consumption of the household was mostly on their kitchen budget, marriage ceremonies and other events instead of on education, health, housing quality and housing service. The value of 0.256 with high significance indicated weak correlation between family income and saving money. The more the households earn, greater or higher will be their savings. Correlation coefficient of -0.500 showed inversely moderate relationship between family income and reasons for not sending children to school. The social situation revealed that less income was the main reason for not sending their children to school. -0.342 showed that family income had highly significant but negatively weak relationship with presence of civic problems. Direction shows that lesser the income of the household more will be the civic 
problems of the households and vice versa. Family income and type of house had moderately strong relationship with 0.500 coefficient. Those households which had high income level had Pucca houses (house made of Baked Bricks). Due to better income level they could improve their housing condition. The value of 0.159 with 0 significance level indicated highly significant but positively weak relationship between family income and occupancy status of the house showing households with lower family income do not have enough money to save and buy their own house as either they were living in a rented house or they were living without paying any rent with relatives. Family income had a very highly significant and moderate relationship with number of rooms in a household with the value of 0.385 . Lower income households' had less number of rooms where more than $60 \%$ of the households were living in a house with one or two rooms. 0.337 showed positively moderately weak relationship between family income and renting part of their house. Those households who were renting part of their house were getting additional income, therefore, increasing their family income slightly. The relationship between family income and satisfaction about overall housing condition was highly significant while correlation of 0.263 showed weak relationship between them. The residents of these katchi abadis didn't have enough income, additional income or savings to change their housing quality; therefore, they were dissatisfied with their housing condition. The relationship between family income and level of multiple deprivation was negatively weak with -0.121 coefficient but highly significant. The situation of the families of these slums indicated that if they had more income they could have fulfilled their number of needs, thus, reducing their level of deprivation.

1.2 Table number 3 (Appendix) shows correlation coefficient of Savings of HHs with four Indicators: The Pearson correlation coefficient of 0.257 indicates the positively weak relationship between the standard of living and saving money. It shows that lesser the people save money, lower will the standard of living. The relationship between saving money and occupancy status of the house was highly significant, with correlation of -0.21 . The direction of the findings showed that those households saved money that did not have to pay rent or they own their place of living or had a lease of their land. The relationship between saving money and satisfaction about overall housing condition was significant with value of -0.211 , showing lesser the savings, lower the satisfaction about their housing condition. 0.633 indicates a highly significant and positively strong relationship between saving income and spending money on health. Those households who save more money can spend more on the health of their family members.

1.3 Table number 4 (Appendix) shows correlation coefficient of Savings of HHs with nine Indicators: Correlation coefficient of -0.105 indicated that educational level of household head and number of family members were inversely weakly correlated but with high significance level of 0.010 . This phenomenon is seen in 
all low income communities and in this case katchi abadis that when educational level is low the size of family is large as they have low income due to unavailability of better employment, they try to increase their number of children who will be their source of income. The values; 0.133 and 0.103 with 0.002 and 0.011 significance level respectively, pointed out that the relationship of educational level (head of the household) with family income and saving money were highly significant but with very weak relationship among them. Dimension of relationship shows that if the households' head educational level was high then their family income was also moderate or high. They also saved money because they had awareness and understanding about the importance of saving money. There was a highly significant relationship between educational level and households' reasons for not sending their children to school with negative and moderately weak relationship at -0.310 coefficient between variables. The educational level of the head of the household is low and the main reason for not sending their children to school is that the education doesn't have importance to their parents. Educational level (head of the household) had highly significant relationship but positively weak with Occupation (head of the household) and nature of employment with correlation coefficient of 0.206 and 0.127 respectively. Higher the education better was the job of the head of the household. Those heads of the households with better education had full time job which included government jobs, private jobs, own businesses and skilled base jobs. The Pearson's' correlation coefficient value of 0.112 suggests very weak relationship between educational level of the head of the household and immunization of children. The government dispensaries, clinics and hospitals have free service and no charge for the immunization of children but parents do not take them for immunization as they avoid interactions and consider it unimportant due to lack of awareness, therefore, IMR and U5MR are high in slums and squatter settlements. The relationship between educational level (head of the household) and use of family planning method was highly significant with correlation coefficient of 0.148 . The people who were educated or more educated were using family planning methods for birth spacing. The relationship between educational level (head of the household) and reason for not going for treatment was highly significant and coefficient of -0.310 showed negatively weak relationship between them. The households whose head were less educated or illiterate had less awareness about the seriousness of any disease or illness.

1.4 Table no. 5 (Appendix) shows results of indices of deprivation and comparison with district level indices: The multiple deprivation scores showed that 0.48 proportion or $48 \%$ of household in the katchi abadis were deprived multiple domains of deprivation. IMD of the katchi abadies of Karachi is much higher than the national IMD (2012) of 30.3\%. If compared with urban IMD scores; urban IMD (13.3\%) is much lower than the IMD of katchi abadies. The index of education deprivation indicated that $42 \%$ of households were deprived in 
education domain whereas $35.1 \%$ are deprived at National level. The difference shows higher educational deprivation in these households. The scores of the index of economic deprivation and housing quality deprivation pointed out that $40 \%$ of the population were deprived in the said deprivations. Economic deprivation with $46.2 \%$ was at the higher side and housing quality deprivation was at lower side with $31.1 \%$. Housing services deprivation had the least percentage of population deprived i.e. $24 \%$ which is still high with the difference of +4.5 points.

1.5 Table no. 6 shows results of indices of deprivation with residential area: The results indicated that deprivation scores were dissimilar in different settlements. Index of multiple deprivation showed the range from $41 \%$ to $56 \%$; lowest deprivation in Mehran Colony and the highest deprivation in Kutchi Ithad. The findings emphasized that all settlement had deprivation in all domains; however each settlement had different issues and concerns priority wise.

1.6 Table no. 7 shows results of indices of deprivation with area of origin: Index of educational deprivation showed highest scores of 0.49 and 0.48 of the residents; who had originally migrated from India and rural areas of Sindh respectively. $31 \%$ of population, belonging to the rural areas of Punjab, was deprived. Settlers who migrated from rural Sindh, rural Punjab and other places of Karachi had highest percentage of population deprived in the index of economic deprivation. Scores in the index of health deprivation indicated $51 \%$ of residents migrated from India were going through health deprivation.

1.7 Table no. 8 shows results of indices of deprivation with Male and Female headed households: Index of multiple deprivation showed that both male and female headed households had same deprivation scores of 0.48 or $48 \%$. The highest scores in female headed household were in education and economic deprivation i.e. 0.46 and 0.44 respectively, whereas highest scores in male headed household were in health $(0.45)$ and housing quality $(0.43)$ deprivation.

1.8 Table no. 9 shows results of indices of deprivation with poverty line: The outcome of indices of deprivation with poverty line showed $18 \%$ of households living above poverty line were economically deprived whereas $45 \%$ of households living below poverty line were deprived. Index of multiple deprivation showed $49 \%$ of households living below poverty line (US\$ 1.25 ) were going through multiple deprivation whereas 43 percent of households above poverty line were deprived in multiple deprivation.

1.9 Table no. 10 shows results of levels of multiple deprivation The results indicate a very severe state of the people of katchi abadis. $44 \%$ of total households were living in high deprivation condition while 53\% had medium deprivation level. The outcomes of overall multiple deprivation level imply that 
more than $96 \%$ out of total households were experiencing multiple deprivation.

\section{Recommendations}

The causes and symptoms of socio-economic deprivation are overlapping and complicated. It is very important for all the agencies that are providing assistance to arrive at organizational conclusions about such causes, otherwise only the symptoms of deprivation will be considered which is happening in Karachi.

The classification of households according to their size proves that deprivation in Karachi is comparatively pervasive in households with large family size which results in slow improvement in living standards of the people along with their poorer employment conditions than with smaller households. Therefore, government should make efforts to control increase in population of Karachi as the growth rate is already very high at $5.5 \%$.

The finding of this study shows that the male and female headships of household have about the same deprivation scores. Results exhibit that a household headed by a female has the same probability to fall into poverty as male-headed households. Government should take initiative to create female friendly environment and encourage them as a diligent workforce.

The most significant element which distinguishes the poor from the non-poor is their education. It is an essential precondition for reducing deprivation. Over and above this the adult literacy rates in Katchi Abadies are very low. Functional literacy for the household's head and higher secondary education must be a considerable part of Pakistan's national goals if a considerable indent is to be made in levels of socio-economic deprivation.

For reducing the deprivation levels in Karachi the livelihood of the head of the household is vital. It was found that the members of poor households were generally being employed in low paid informal sectors; therefore, government should take concrete steps to increase the wage levels especially in private sector organizations and informal employment sectors. Self-business and selfemployment along with foreign investment should be encouraged as to change the living standard of the people.

Regularization and up gradation of katchi abadies is necessary for the accessibility of full urban services by its inhabitants. The local government of Karachi cannot achieve this task alone therefore collaboration and assistance of NGOs, and community based organisations (CBOs) is also crucial. 
Health deprivation scores have improved due to the involvement of private sector in providing health facilities. The current IMR, U5MR and MMR have gone down. These encouraging changes indicate increasing levels of awareness of education, availability of health facilities and family planning programmes adopted by an increasing number of youngsters in Karachi. Thus, health deprivation can be further reduced by encouraging the private sector and healthrelated NGOs.

Most of Katchi Abadies are connected to a sewer running along the side of their roads. Majority of the households in these katchi abadies dump their waste water in open spaces or in tanks. The consequences of this disposal had led to environmental degradation. Concrete measures such as construction of proper sewage system in all katchi abadis of Karachi. The NGOs and civil society can accomplish a very important task in the development of katchi abadis as OPP (Orange Pilot Project, 2004) has already constructed sewage system in about 50\% of katchi abadies of Karachi.

Government can neither be entirely blamed nor completely held responsible for all the socio-economic problems and they also cannot single-handedly solve all the problems. An integrated approach with community participation is the key factor in long-lasting results and solution of majority of the issues related to socio-economic deprivation. An integrated, multi-level approach should be used for problem-solving which involves participation of a variety of stakeholders. Formulation of strategy is fundamental for the development of slums and squatter settlements involving KMC (Karachi Municipal Corporation), NGOs, donors, civil society and corporate sector.

\section{References}

Abbas, S., Rashid, M. \& Ansari, K. (2010). Pattern of Karachi katchi-abadies. Journal of Basic and Applied Sciences, vol.6:2, pp.119-134.

ADB. (2012). Asian Development Outlook 2012; Confronting Rising Inequality in Asia. Philippines: Asian Development Bank.

Asghar, J. H. (1984). A Study of Socio-Economic Conditions of Females in Katchi Abadi, Chaudry Colony, Lahore. Department of Social Work, Punjab University, Lahore.

Aurora. G. S. (2004). Poverty and Economic Reforms: The Social Concerns. India. Academic Foundations, Institute for Social and Economic Change (ISEC) Banglore, India. 
Babbie, E. (2004). The Practice of Social Research $\left(10^{\text {th }}\right.$ ed.). Belmont: Wadsworth \& Thomson.

Balquees, F. \& Hamid, S. (1989). Socio-Economic Profile of Poor Women in Katchi Abadis; Report of Survey in Rawalpindi. Pakistan Institute of Development Economics (PIDE).

CDGK (City District Government of Karachi). (2011). Estimated Population Projection till 2050. Retrieved from the CDGK official website: www.karachicity.gov.pk.

Chaudhry, N.A. (1991). Community Development in Katchi Abadis/Slums Project. Unpublished Report, Pakistan Family Council, Lahore.

Government of Pakistan. (2013). Economic Survey of Pakistan: 2012-2013. Islamabad: Finance Division Economic Advisor's Wing.

Hina, I. (1992). Role of Government in the Improvement of Katchi Abadis. (Unpublished thesis), Government College Lahore.

Human Development Report. (2013). Rise of the South: Human Progress in a Diverse World. UNDP Canada: Gilmore Printing Services Inc.

Human Development Report. (2015). Work for Human Development. UNDP New York: PBM Graphics.

Idrees, M. \& Ahmed, E. (2002). Trends in Income in Equality in Pakistan. Proceedings Seventeenth Annual General Meeting Jan 14-16, 2002 Islamabad, Pakistan Institute of Development Economic.

Jamal, H. \& Khan A. J. (2007). Indices of Multiple Deprivation 2005. Social Policy and Development Centre, Research Report 72.

Jamal, H. (2012). Districts' Indices of Multiple Deprivations for Pakistan 2011. Social Policy Development Centre, Research Report 82.

Jamal, H., Khan A. J., Toor, I. A. \& Amir, N. (2003). Mapping the Spatial Deprivation of Pakistan. Social Policy Development Centre, Research Report $52,91-111$.

Kalim, R., \& Bhatty, S. A. (2006). Quantification of Socio Economic Deprivations of Squatter settlement's Inhabitants: A Case Study of Lahore. 
Proceedings of 6th Global Conference on Business \& Economics October 1517, 2006 Gutman Conference Centre, USA.

Kazmi, S. (1999). Attitude of Residents of Katchi Abadis and Slums Towards Low-Cost; Multi-Storeyed Housing. Unpublished Thesis, Punjab University.

Kemal, A.R. \& Mahmood Z. (1998). The Urban Informal Sector of Pakistan; Some Stylized Facts. Islamabad: Pakistan Institute of Development Economics.

Linden, J. V. D. \& Selier F. (1990). Karachi Migrants Housing and Housing Policy. Lahore: Vanguard Books Ltd.

Manzoor, M. M., Essa, R., Vaswani, S. L., Aleem, M. \& Usman, M. Sh. (2011). Cities Growth and Health Challenges of Poor People's Living in Slums of Urban Areas - Case from Karachi. Proceedings of $8^{\text {th }}$ International Conference On Recent Advances In Statistics Lahore Pakistan - February 8-9, Islamic Countries Society of Statistical Sciences, 20, 187-192.

OPP (Orangi Pilot Project). (2004). Katchi Abadis of Karachi: A Survey of 334 Katchi Abadis. Karachi: Orangi Pilot Project-Research and Training Institute.

Oxford Poverty \& Human Development Initiative (OPHI). (2013) A Country Brief for Pakistan's MPI 2013. Oxford Department of International Development, Retrieved from http://www.ophi.org.uk/wpcontent/uploads/ Pakistan.pdf.

Oxford Poverty \& Human Development Initiative (OPHI). (2015) A Country Brief for Pakistan's MPI 2015. Oxford Department of International Development, retrieved from http://www.ophi.org.uk/wpcontent/uploads/ ophi-wp-591.pdf in 2015.

Pasha, H. A. \& Pasha, A. G. (2002). Cost of Living by City in Pakistan. Social Policy and Development Centre, Research Report 43.

Qadeer, M. (1983). Urban Development in the Third World: City Planning; Case Studies; Lahore. Vanguard Books, 190-192.

Qureshi, A. B. (1982-84). The Situation of Children Living in Katchi Abadis. Unpublished Thesis, Punjab University.

Qureshi, J. A. \& Ali D. K. (1988). Socio-Economic Profile of a City Slum. Punjab Economic Research Institute. 
Qureshi, S. (2010). The Fast Growing Megacity Karachi as a Frontier of Environmental Challenges: Urbanization and Contemporary Urbanism Issues. Journal of Geography and Regional Planning, 3(11), 306-321. Retrieved from http://www.academicjournals.org/JGRP.

SKAA. (2006). A Presentation on Katchi Abadis of Karachi. Karachi: Sindh Katchi Abadis Authority Karachi.

SPDC (Social Policy and Development Centre). (2001). Growth, Inequality and Poverty Social Development in Pakistan: Annual Review. Karachi. Oxford University Press.

The World Bank. (2002). Pakistan Poverty Assessment; Poverty in Pakistan: Vulnerabilities, Social Gaps, and Rural Dynamics. New York: Oxford University Press.

Townsend, P., Phillimore, P. \& Beattie, A. (1988). Health and Deprivation: Inequality and the North. London: Routledge.

UNDP Report. (1997). Human Development Report:1997. United Nations Development Programme. New York. Oxford University Press.

United Nations Human Settlements Programme. (2011) State of the World's Cities 2010/2011: Bridging the Urban Divide. UN HABITAT.

WHO (World Health Organization). (2012). World health statistics: 2012. France: WHO Press.

World Bank. (2007). Development and the Next Generation. Washington DC: World Bank.

World Bank. (2012). The World Development Report 2012: Gender Equality and Development. Washington DC: World Bank.

Zaman, A. \& Ara I. (2002). Rising Urbanization in Pakistan. The Journal NIPA, vol.7:3. 


\section{Appendix}

Table: 2

\begin{tabular}{|l|c|c|c|}
\hline \multicolumn{1}{|c|}{$\begin{array}{c}\text { Relationships of Family Income of } \\
\text { Household With }\end{array}$} & $\begin{array}{c}\text { Pearson's } \\
\text { Corr. }\end{array}$ & $\begin{array}{c}\text { Sig. (1- } \\
\text { tailed) }\end{array}$ & N \\
\hline Standard of Living & -0.289 & .000 & 497 \\
\hline Saving Money & .256 & .000 & 497 \\
\hline Reasons for not Going to School & -.500 & .000 & 497 \\
\hline Civic Problems & -.342 & .000 & 497 \\
\hline Type of House & .500 & .000 & 497 \\
\hline Occupancy Status of House & .159 & .000 & 497 \\
\hline Numbers of Rooms & .385 & .000 & 497 \\
\hline Renting Part of House & .337 & .000 & 497 \\
\hline Facilities in the House & -.193 & .000 & 497 \\
\hline $\begin{array}{l}\text { Satisfaction about Overall Housing } \\
\text { Condition }\end{array}$ & .263 & .000 & 497 \\
\hline Level of Multiple Deprivation & -.121 & .003 & 497 \\
\hline
\end{tabular}

Table: 3

\begin{tabular}{|l|c|c|c|}
\hline $\begin{array}{c}\text { Relationship of Saving Income by Hhs } \\
\text { With }\end{array}$ & $\begin{array}{c}\text { Pearson's } \\
\text { Corr. }\end{array}$ & $\begin{array}{c}\text { Sig. (1- } \\
\text { tailed) }\end{array}$ & N \\
\hline Standard of Living & .257 & .000 & 497 \\
\hline Occupancy Status of House & -0.20 & .000 & 497 \\
\hline Satisfaction about Housing Condition & -.211 & .000 & 497 \\
\hline Spend Savings on Health & .633 & .000 & 497 \\
\hline
\end{tabular}

Table: 4

\begin{tabular}{|l|c|c|c|}
\hline \multicolumn{1}{|c|}{$\begin{array}{c}\text { Relationship of Educational } \\
\text { Qualification With }\end{array}$} & $\begin{array}{c}\text { Pearson } \\
\text { Corr. }\end{array}$ & $\begin{array}{c}\text { Sig. (1- } \\
\text { tailed) }\end{array}$ & N \\
\hline Family Size & -.105 & .010 & 497 \\
\hline Total Income of Household (In Rs) & .133 & .002 & 497 \\
\hline Saving Money & .103 & .011 & 497 \\
\hline $\begin{array}{l}\text { Reasons for not Sending Children to } \\
\text { School }\end{array}$ & -.310 & .011 & 55 \\
\hline Occupation (Head of Hh) & -.206 & .000 & 497 \\
\hline Nature of Employment & .127 & .002 & 497 \\
\hline Immunization of Children & .112 & .006 & 497 \\
\hline Use of Family Planning Method & .148 & .000 & 497 \\
\hline Reason for not Going for Treatment & -.310 & .010 & $55^{*}$ \\
\hline
\end{tabular}


Table: 5

Indices of Deprivation

[Percentage of Population Deprived in terms of Selected Indices]

\begin{tabular}{|l|c|c|}
\hline Overall Deprivation (\%) & $\begin{array}{c}\text { Weighted by } \\
\text { Household Size }\end{array}$ & Weight Off \\
\hline Index of Multiple Deprivation & 48 & 47 \\
\hline Index of Education Deprivation & 42 & 39 \\
\hline Index of Economic Deprivation & 40 & 36 \\
\hline Index of Health Deprivation & 42 & 41 \\
\hline $\begin{array}{l}\text { Index of Housing Quality } \\
\text { Deprivation }\end{array}$ & 39 & 40 \\
\hline $\begin{array}{l}\text { Index of Housing Services } \\
\text { Deprivation }\end{array}$ & 24 & 27 \\
\hline
\end{tabular}

Table: 6

Indices of Deprivation by Residential Areas

[Percentage of Population Deprived in term of Selected Indicators]

\begin{tabular}{|l|c|c|c|c|c|c|c|}
\hline \multirow{2}{*}{$\begin{array}{l}\text { Domains of } \\
\text { Deprivation }\end{array}$} & \multicolumn{7}{|c|}{ Katchi Abadis/Residential Areas } \\
\cline { 2 - 9 } & $\begin{array}{c}\text { Adam } \\
\text { Hingoro }\end{array}$ & $\begin{array}{c}\text { Bilal } \\
\text { Colony }\end{array}$ & $\begin{array}{c}\text { Kutchi } \\
\text { Ithad }\end{array}$ & $\begin{array}{c}\text { Mehran } \\
\text { Colony }\end{array}$ & $\begin{array}{c}\text { Muslim } \\
\text { Abad }\end{array}$ & $\begin{array}{c}\text { Nazir } \\
\text { Town }\end{array}$ & $\begin{array}{c}\text { Qasim } \\
\text { Abad }\end{array}$ \\
\hline $\begin{array}{l}\text { Index of Multiple } \\
\text { Deprivation }\end{array}$ & 45 & 52 & 56 & 41 & 48 & 47 & 50 \\
\hline $\begin{array}{l}\text { Index of Education } \\
\text { Deprivation }\end{array}$ & 37 & 52 & 70 & 50 & 49 & 30 & 61 \\
\hline $\begin{array}{l}\text { Index of Economic } \\
\text { Deprivation }\end{array}$ & 35 & 39 & 45 & 36 & 42 & 43 & 54 \\
\hline $\begin{array}{l}\text { Index of Health } \\
\text { Deprivation }\end{array}$ & 47 & 50 & 46 & 22 & 41 & 39 & 27 \\
\hline $\begin{array}{l}\text { Index of Housing } \\
\text { Quality Deprivation }\end{array}$ & 47 & 51 & 45 & 22 & 27 & 35 & 24 \\
\hline $\begin{array}{l}\text { Index of Housing } \\
\text { Services Deprivation }\end{array}$ & 9 & 11 & 6 & 23 & 38 & 43 & 38 \\
\hline
\end{tabular}


Table: 7

Indices of Deprivation by Households' Area of Origin [Percentage of Population Deprived in term of Selected Indicators]

\begin{tabular}{|l|c|c|c|c|}
\hline \multirow{2}{*}{ Indices of Deprivation } & \multicolumn{4}{|c|}{ Household Area of Origin } \\
\cline { 2 - 5 } & Sindh-Rural & Punjab-Rural & India & Karachi \\
\hline $\begin{array}{l}\text { Index of Multiple } \\
\text { Deprivation }\end{array}$ & 48 & 48 & 48 & 48 \\
\hline $\begin{array}{l}\text { Index of Education } \\
\text { Deprivation }\end{array}$ & 48 & 31 & 49 & 42 \\
\hline $\begin{array}{l}\text { Index of Economic } \\
\text { Deprivation }\end{array}$ & 43 & 40 & 23 & 40 \\
\hline $\begin{array}{l}\text { Index of Health } \\
\text { Deprivation }\end{array}$ & 36 & 42 & 51 & 43 \\
\hline $\begin{array}{l}\text { Index of Housing } \\
\text { Quality Deprivation }\end{array}$ & 31 & 48 & 39 & 40 \\
\hline $\begin{array}{l}\text { Index of Housing } \\
\text { Services Deprivation }\end{array}$ & 33 & 23 & 32 & 22 \\
\hline
\end{tabular}

Table: 8

Indices of Deprivation by Household Headship [Percentage of Population Deprived in term of Selected Indicators]

\begin{tabular}{|l|c|c|}
\hline \multirow{2}{*}{ Indices of Deprivation } & \multicolumn{2}{|c|}{ Household Headship } \\
\cline { 2 - 3 } & Male & Female \\
\hline Index of Multiple Deprivation & 48 & 48 \\
\hline Index of Education Deprivation & 40 & 46 \\
\hline Index of Economic Deprivation & 37 & 44 \\
\hline Index of Health Deprivation & 45 & 37 \\
\hline Index of Housing Quality Deprivation & 43 & 36 \\
\hline Index of Housing Services Deprivation & 21 & 28 \\
\hline
\end{tabular}

Table: 9

Indices of Deprivation by Household Poverty Line

[Percentage of Population Deprived in term of Selected Indicators]

\begin{tabular}{|l|c|c|}
\hline Indices of Deprivation & \multicolumn{2}{|c|}{ Households Poverty Line } \\
\cline { 2 - 3 } & $\begin{array}{c}\text { Above Poverty } \\
\text { Line }\end{array}$ & $\begin{array}{c}\text { Below } \\
\text { Poverty Line }\end{array}$ \\
\hline Index of Multiple Deprivation & 43 & 49 \\
\hline Index of Education Deprivation & 20 & 47 \\
\hline Index of Economic Deprivation & 18 & 45 \\
\hline Index of Health Deprivation & 44 & 41 \\
\hline Index of Housing Quality Deprivation & 44 & 39 \\
\hline Index of Housing Services Deprivation & 20 & 25 \\
\hline
\end{tabular}


Table: 10

Levels of Multiple Deprivation

\begin{tabular}{|l|c|c|c|}
\hline $\begin{array}{c}\text { Multiple Deprivation } \\
\text { Levels }\end{array}$ & Frequency & $\begin{array}{c}\text { Percent } \\
\text { \% }\end{array}$ & $\begin{array}{c}\text { Cumulative } \\
\text { Percent }\end{array}$ \\
\hline High Deprivation & 219 & 44.06 & 44.06 \\
\hline Medium Deprivation & 263 & 52.92 & 96.98 \\
\hline Low Deprivation & 15 & 3.02 & 100.0 \\
\hline Total & 497 & 100.0 & \\
\hline
\end{tabular}

Dr. Kaneez Fatima Mamdani is an Assistant Professor in the Department of Sociology, University of Karachi. 